\title{
ANALISIS PENERAPAN AKAD WAKALAH PADA PRODUK PENDANAAN SUKUK TABUNGAN (SBSN) MELALUI LAYANAN FINANCIAL TECHNOLOGY SYARIAH (Studi Kasus PT. Investree Radhika Jaya)
}

\author{
Siti Kurnia Primanilisa ${ }^{1} \&$ Rahmatul Fadhil ${ }^{2}$
}

\section{Abstrak}

Penelitian ini dilakukan untuk mengetahui bagaimana mekanisme penjualan Sukuk Tabungan di Investree, apakah penjualan Sukuk Tabungan di Investree telah sesuai Peraturan dalam Memorandum Informasi. Kemenkeu, dan apakah penjualan Sukuk Tabungan di Investree telah sesuai berdasarkan Fatwa DSN MUI No. 95/DSNMUI/VII/2014 Tentang SBSN Wakâlah. Adapun Penelitian ini merupakan penelitian lapangan (field research), yang mana pengumpulan data primer dilakukan dengan metode wawancara, sedangkan untuk data sekunder penulis menggunakan dokumen, jurnal, peraturan, buku-buku, dan karya ilmiah yang berkaitan dengan teori SBSN/sukuk, fintech, dan wakâlah. Setelah data penelitian terkumpul selanjutnya penulis melakukan analisis menggunakan metode deskriptif kualitatif. Dari penelitian mengenai mekanisme penjualan yang berlaku di Investree, penulis menyimpulkan bahwasanya praktik penjualan Sukuk Tabungan di PT Investree Radhika Jaya telah sesuai dengan Memorandum Informasi Sukuk Tabungan Kemenkeu dan Fatwa Dewan Syariah Nasional-Majelis Ulama Indonesia No. 95/DSN-MUI/VII/2014 Tentang SBSN Wakâlah. Analisis yang dilakukan penulis yaitu dengan mengkaji apa yang terjadi di Investree terhadap Memorandum Informasi fatwa dan Kemenkeu. DSN-MUI. Adapun pedoman untuk tersebut yakni Memorandum Informasi Sukuk Tabungan seri ST-006 tahun 2019 yang diterbitkan oleh Pemerintah Republik Indonesia dan Fatwa DSN MUI Nomor 95/DSN-MUI/VII/2014 Tentang SBSN Wakâlah.

Kata Kunci: SBSN, Sukuk Tabungan, Wakâlah, Fintech, Investree

\section{Abstract}

This research was conducted to find out how the sales mechanism of Sukuk Tabungan at Investree, whether the sale of Sukuk Tabungan at Investree has complied with the Regulations in the Ministry of Finance's Information Memorandum, and whether the sale of Sukuk Tabungan at Investree is in accordance with the MUI DSN Fatwa No.95/DSNMUI/VII/2014 concerning SBSN Wakâlah. This research is a field research (field research), in which primary data collection is carried out by the interview method, while for secondary data the authors use documents, journals, regulations, books, and scientific papers related

\footnotetext{
${ }^{1}$ Alumni Institiut Ilmu Al Qur'an Jakarta.

${ }^{2}$ Dosen Institiut Ilmu Al Qur'an Jakarta.
} 
to the theory of SBSN/ sukuk, fintech, and wakalah. After the research data was collected, the authors conducted an analysis using a qualitative descriptive method. From research on the sales mechanism that applies to Investree, the authors conclude that the selling practice of Sukuk Tabungan at PT Investree Radhika Jaya is in accordance with the Ministry of Finance's Sukuk Tabungan Information Memorandum and the Fatwa of the National Sharia Council-Indonesian Ulama Council No. 95/DSN-MUI/VII/2014 concerning SBSN Wakâlah. The analysis carried out by the author is by examining what happened in the Investree to the Ministry of Finance's Information Memorandum and the DSN-MUI Fatwa. The guidelines for this are the Memorandum of Sukuk Tabungan Information series ST-006 year 2019 issued by the Government of the Republic of Indonesia and the MUI DSN Fatwa Number 95/DSN-MUI/VII/2014 concerning SBSN Wakâlah.

Keywords: SBSN, Sukuk Tabungan, Wakâlah, Fintech, Investree

\section{A. PENDAHULUAN}

Salah satu hal yang ditawarkan dalam ekonomi Islam ini adalah mengembangkan sistem keuangan bagi hasil atau tanpa bunga agar ekonomi Islam dapat memperbaiki sistem keuangan dengan pendekatan menyeluruh. Salah satu instrumen syariah dalam pasar modal ialah Surat Berharga Syariah Negara atau yang lebih dikenal dengan istilah sukuk. Surat Berharga Negara untuk investor ritel adalah produk investasi yang diterbitkan oleh pemerintah dan dijual kepada individu Warga Negara Indonesia (WNI) melalui Agen Penjual. Terdiri dari 2 jenis yaitu konvensional dan syariah, untuk konvensional yaitu Obligasi Negara Ritel (ORI) dan Savings Bond Ritel (SBR). Sedangkan jenis syariah adalah Sukuk Negara Ritel (SR) dan Sukuk Negara Tabungan (ST) (www.djppr.kemenkeu.go.id).

Menurut fatwa DSN-MUI No.32/DSN-MUI/IX/2002 Tentang obligasi syariah, obligasi syariah adalah suatu surat berharga jangka panjang berdasarkan prinsip syariah yang dikeluarkan emiten kepada pemegang sukuk yang mewajibkan emiten untuk membayar pendapatan kepada pemegang sukuk berupa bagi hasil/margin/ fee serta membayar kembali dana obligasi pada saat jatuh tempo (Fatwa DSN-MUI No.32/DSN-MUI/IX/2002 tentang Obligasi Syariah).

Untuk keperluan menyediakan payung hukum dan memberikan kepastian hukum bagi para pihak yang berivestasi dengan mengunakan Surat Berharga Syariah Negara, Pemerintah Indonesia juga telah menerbitkan peraturan perundang-undangan mengenai sukuk negara dengan beberapa peraturan, diantaranya UU No. 19 
Tahun 2008 tentang Surat Berharga Syariah Negara yang kemudian dilengkapi dengan Peraturan Pemerintah No. 56 Tahun 2008 tentang Perusahaan Penerbit SBSN dan Peraturan Pemerintah No. 57 Tahun 2008 Tentang Pendirian Perusahaan Penerbit SBSN (Kusumaputra, 2009). Disamping Peraturan Hukum yang kuat, mekanisme pelaksanaan jual beli sukuk negara ini juga diatur dalam beberapa fatwa yang diterbitkan oleh DSN-MUI.

Seiring dengan perkembngan zaman, jual beli ini tidak hanya dilakukan dalam dengan tatap muka antara penjual dan pembeli. Kecangihan teknologi dewasa ini memungkin para penjual dan pembeli bertransaksi melalui media online (platform digital). Bidang ekonomi merupakan salah satu bidang yang mendapat manfaat langsung dari adanya kemajuan teknologi ini. Karena penjual dan pembeli dapat bertransaksi tanpa terbatas oleh jarak dan waktu. Pesatnya perkembangan teknologi tidak hanya merambah dunia perdagangan tetapi juga dunia keuangan.

Hal ini ditandai dengan munculnya Financial Tecnology (Fintech) yang memberikan kemudahan dalam mempertemukan Lender (Pemilik Modal) dengan Borrower (Peminjam dana). Karena pesatnya pertumbuhan fintech dari tahun ke tahun, maka Otoritas Jasa Keuangan (OJK) sebagai pengatur dan pengawas jasa keuangan berperan aktif dalam mengawasi perkembangan penyelenggaraan Financial Tecnology agar sesuai dengan perturan OJK No. 77/POJK.01/2016 tentang layanan pinjam meminjam uang berbasis teknologi informasi, karena dalam opininya masih banyak terjadi pelanggaran, khususnya mengenai pendaftaran dan perizinan penyelenggraan di OJK (Praman, et. al., 2014:1).

Saat ini kementrian keuangan bekerja sama dengan beberapa bank dan perusahaan dalam mendistribusikan pendanaan surat berharga syariah negara. Bank umum yang terlibat di antaranya adalah Bank Mandiri, Mandiri Syariah, BRI, BRI Syariah, Muamalat, BCA, BNI, BTN, Permata Bank, Panin Bank, MayBank, CIMB Niaga, DBS, OCBC NISP, dan HSBC. Sedangkan perusahaan efek maupun fintech yang terlibat diantaranya yaitu Trimega, Danareksa, Mandiri Sekuritas, Tanamduit, Bareksa, Invisee, Modalku serta Investree (Direktorat Pembiyaan syariah Kementrian Keuangan RI, 2019).

PT. Investree Radhika Jaya (Investree) sebagai satu-satunya agen penjualan yang merupakan perusahaan fintech syariah serta mendapat

ANALISIS PENERAPAN AKAD WAKALAH PADA PRODUK 
izin usaha dari OJK. Perusahaan ini adalah perusahaan fintech swasta dengan jenis peer to peer lending. Pada awal 2018 Investree telah resmi mengantongi izin terdaftarnya layanan berbasis syariah dengan nomor surat $114 / \mathrm{NB} / 233 / 2018$ yang berkaitan dengan produk invoice syariah (Aldila, 2019).

Kemudian pada 13 Mei 2019 Investree juga telah mengantongi izin menjalankan usaha perusahaan penyelenggara layanan pinjam meminjam uang berbasis teknologi Informasi yang tetuang dalam putusan OJK Kep-45/D.05/2019 (Rahayu, 2019). Hingga April 2019 investree Syariah telah tercatat menyalurkan dana kepada para nasabahnya sebesar 69 Miliyar. Hal ini menunjukan pembiayaan yang dilakukan investree amat signifikan. Secara umum pada mei 2019 jumlah lender aktif di Invstree sudah mencapai 14.375 orang yang tersebar di seluruh wilayah Indonesia, sedangkan borrower sudah mencapai 1.084 UMKM (Zuraya \& Wulandari, 2019).

Selain dapat memberikan pendanaan kepada UMKM, para lender di Investree juga bisa memberikaan pendanaan pada Surat Berharga Negara (SBN) dan reksa dana. Pendanaan pada Surat Berharga Syariah Negara yang ditawarkan ialah dalam bentuk sukuk ritel dan tabungan. Sukuk Tabungan disini adalah salah satu Surat Berharga Syariah Negara (SBSN) yang merupakan instrumen Investasi berbasis syariah yang diterbitkan oleh pemerintah melalui Kementrian Keuangan Republik Indonesia dan ditunjukan bagi Investor Individu Warga Negara Indonesia. Pendanaan ini diberikan dalam rangka untuk mendukung pembangunan nasional melalui Investasi Syariah Penerbitan Sukuk ini memang sudah lama dilakukan oleh pemerintah dan sudah diterbitkan peraturan yang menaungi mekanisme jual belinya, baik dari peraturan perundang-undangan, peraturan OJK hingga fatwa DSN-MUI. Seiring dengan kemajuan teknologi saat ini, maka proses pendanaanya melalui Financial Tecnology merupakan hal yang baru. Maka bagaimana implementasi pendanaan sukuk Tabungan dengan akad SBSN wakâlah yang dilakukan secara online ini? Apakah telah sesuai dengan fatwa yang dikeluarkan oleh DSNMUI No.95/DSN-MUI/VII/2014 tentang SBSN Wakâlah.

Berdasarkan latar belakang yang telah dipaparan di atas, maka dapat dirumuskan masalah sebagai berikut: 
a. Bagaimana Mekasnisme Penerapan Akad Wakâlah pada produk pendanaan sukuk tabungan (SBSN) melalui layanan Financial Technology Syariah di PT. Investree Radhika Jaya?

b. Apakah produk pendanaan sukuk tabungan (SBSN) melalui layanan Financial Technology Syariah di PT. Investree Radhika Jaya telah sesuai dengan Memorandum Informasi Kementerian Keuangan Republik Indonesia?

c. Apakah produk pendanaan sukuk tabungan (SBSN) melalui layanan Financial Technology Syariah di PT. Investree Radhika Jaya telah sesuai dengan fatwa DSN-MUI No.95/DSNMUI/VII/2014 tentang SBSN Wakâlah?

\section{B. KAJIAN TEORITIS}

\section{Definisi Sukuk Negara (SBSN)}

Kata sukuk adalah bentuk plural atau jamak dari kata sakk yang merupakan istilah yang bersumber dari bahasa arab yang dapat diartikan sertifikat. Istilah tersebut sudah dikenal sejak abad pertengahan, dimana umat Islam menggunakanya dalam konteks perdagangan internasional. Sukuk dipergunakan oleh para pedagang pada masa itu sebagai dokumen yang menunjukan kewajiban finansial yang timbul dari usaha perdagangan dan aktivitas komersil lainya. Namun sejumlah penulis barat yang memiliki concern terhadap sejarah Islam dan bangsa Arab menyatakan, bahwa dari kata sakk inilah yang kemudian menjadi akar kata "cheque" dalam bahasa latin, sebagai suatu istilah yang lazim dipergunakan dalam transaksi dunia perbankan kontemporer (Huda \& Nasution, 2008:136).

Dari pengertian diatas, beberapa lembaga terkait mengartikan Sukuk Negara atau Surat Berharga Syariah Negara (SBSN) sebagai berikut:

a. Menurut Undang-Undang Nomor 19 Tahun 2008 dan fatwa DSNMUI No.69/DSN-MUI/VI/2008 tentang Surat Berharga Syariah Negara, yang dimaksud dengan SBSN atau sukuk negara adalah surat berharga negara yang diterbitkan berdasarkan prinsip syariah, sebagai bukti bagian penyertaan terhadap aset SBSN, baik dalam mata uang rupiah maupun valuta asing (Undang-Undang Nomor 19 tahun 2008 tentang Surat Berharga Syariah Negara).

b. Menurut Accounting and Auditing Organization for Islamic Financial Instituion (AAOIFI), Sesuai Sharia Standar No.17 tentang 
Invesment sukuk, pengertian sukuk adalah Invesment sukuk are certifikates of equal value representing undivided shares in ownership of tangible assets, usufruct and servies or (in the ownership of) the assets or particular project or spesial invesment activity (AAOIFI).

Artinya sukuk didefinisikan sebagai sertifikat bernilai sama yang merupakan bukti atas bagian kepemilikan yang tak terbagi terhadap suatu aset, hak manfaat, dan jasa-jasa, atau atas kepemilikan suatu proyek atau kegiatan investasi tertentu (Direktorat Pembiayaan Syariah, 2010).

c. Dalam Keputusan Ketua Badan Pengawas Pasar Modal dan Lembaga Keuangan No:KEP-130/BL/2006 tentang Penerbitan Efek Syariah, istilah sukuk diartikan sebagai efek syariah berupa sertifikat atau bukti kepemilikan yang bernilai sama dan mewakili bagian penyertaan yang tidak terpisahkan atau tidak terbagi lagi atas: (1) kepemilikan aset berwujud tertentu; (2) nilai manfaat dan jasa atas aset proyek tertentu atau aktivitas investasi tertentu; atau (3) kepemilikan atas aset proyek tertentu atau aktivitas investasi tertentu.

Dari pengertian di atas penulis menyimpulkan bahwa sukuk adalah Surat Berharga Syariah Negara yang diterbitkan berdasarkan prinsip syariah sebagai bukti penyertaan atas kepemilikan aset berwujud tetentu yang memiliki nilai manfaat dan jasa baik dalam bentuk mata uang rupiah maupun valuta asing.

\section{Financial Tecnology}

\section{Pengertian Financial Tecnology}

Besarnya pemanfaatan teknologi digital di Indonesia berdampak pada beberapa sektor, salah satunya adalah sektor bisnis yang kemudian melahirkan perdagangan online atau e-commerce. Maka hal ini juga berdampak pada sektor keuangan Indonesia, yang kemudian ditandai dengan lahirnya beberapa fintech yang hadir ditengah masyarakat.

Fintech sendiri berasal dari kata financial technology atau Teknologi Finansial. Peraturan Bank Indonesia No. 19/12/PBI/2017 menjelaskan bahwa Teknologi Finansial adalah penggunaan teknologi dalam sistem keuangan yang menghasilkan produk, layanan, teknologi, dan atau model bisnis baru serta dapat berdampak pada 
stabilitas moneter, stabilitas sistem keuangan, dan atau profesionalitas, efisiensi, kelancaran, keamanan, dan keandalan sistem pembayaran.

The National Digital Research Centre (NDRC) Irlandia mendefinisikan bahwa fintech sebagai inovasi dalam layanan keuangan pada sektor finansial yang mendapat sentuhan teknologi modern. Transaksi keuangan melalui fintech juga meliputi pembayaran, investasi, peminjaman uang, transfer, rencana keuagan dan pembanding produk keuangan (Santi, et. al., 2017:2). Maka dengan itu istilah platform fintech lebih berpusat kepada perusahaanperusahaan di bidang jasa keuangan yang melakukan inovasi dengan sentuhan teknologi modern (Peraturan Bank Indonesia No. 19/12/PBI/2017 tentang Penyelenggaraan Teknologi Finansial).

Secara spesifik fintech didefinisikan sebagai aplikasi teknologi digital untuk masalah-masalah intermediasi keuangan. Lebih luas lagi fintech didefinisikan sebagai sebuah industri yang terdiri dari perusahaan-perusahaan yang menggunakan teknologi agar sistem keuangan serta penyampaian layanan keuangan lebih efisien. Dari beberapa pengertian di atas dapat disimpulkan bahwa fintech adalah inovasi dalam sistem keuangan melalui teknologi informasi untuk meningkatkan efektivitas dan efisiensi kegiatan layanan keuangan guna memecahkan masalah-masalah intermediasi keuangan (Darmawansyah \& Aguspriyani, 2019: 217-218).

Maka fintech syariah yaitu platform financial technology yang menawarkan produk-produk halal dimana transaksinya berdasarkan akad-akad syariah. Hubungan pihak-pihak yang terjadi dalam financial tecnology juga memiliki landasan hukum yang diawasi dan diatur dalam peraturan Otoritas jasa keuangan No.77/POJK.01/2016 tentang Layanan Pinjam Meminjam Uang Berbasis Teknologi Informasi. Selain itu Fintech Syariah juga memiliki acuan berupa fatwa DSN-MUI yang tertuang dalam fatwa No. 117/DSN-MUI/II/2018 tentang Pembiayaan Berbasis Teknologi Informasi berdasarkan Prinsip Syariah.

\section{Penerapan Prinsip Syariah pada Financial Tecnology}

Pada dasarnya aspek kesesuaian dengan prinsip syariah merupakan hal mendasar yang membedakan antara Penyelenggara layanan konvensional dengan penyelenggaran layanan syariah, karena dalam layanan syariah tidak hanya mencari profit oriented, namun juga falah oriented dimana tidak hanya keuntungan semata mata yang di dicari namun kemenangan di dunia dan di akhirat menjadi salah satu yang 
ingin dicapai dalam penyelenggaraan layanan ini (Basuki) (Trisnadi \& Shomad, 2005:50).

Penyelengaraaan teknologi informasi yang berdasarkan akad syariah memberikan beberapa pilihan kepada para pengguna layanan, baik peminjam maupun pihak yang memberikan pinjaman. Peminjam maupun pemberi pinjaman diberikan skema sesuai kebutuhan mereka namun tetap sesuai koridor syariah. Penerapan skema syariah yang dilakukan penyenggara wajib memperhatikan ketentuan yang ditetapkan oleh regulator agar memberikan pelayanan yang maksimal serta perlindungan dan kepastian bagi pengguna layanan. Skema

Akad yang di terapkan oleh penyelenggara layanan berbeda-beda tergantung dengan skema dan kebutuhan penerima pinjaman (Alwi, 2018). Salah satu aturan yang harus dipatuhi oleh penyelenggara fintech yaitu peraturan dari otoritas jasa keuangan yang tertuang dalam POJK Nomor 77/POJK.01/2016 sebagai dasar penyelenggaran layanan pinjam meminjam berbasis teknologi informasi. Di dalamnya terdapat ketentuan tentang penerima pinjaman dan pemberi pinjaman, sebagai berikut:

a. Penerima Pinjaman harus berasal dan berdomisili di wilayah hukum Negara Kesatuan Republik Indonesia.

b. Penerima Pinjaman terdiri dari orang perseorangan warga negara Indonesia atau badan hukum Indonesia (Peraturan Otoritas Jasa Keuangan Nomor 77 tahun 2016 tentang Penyelenggaran Layanan Pinjam Meminjam Berbasis Teknologi Info Pasal 15).

c. Pemberi Pinjaman dapat berasal dari dalam dan/atau luar negeri.

d. Pemberi Pinjaman terdiri dari:

i. orang perseorangan warga negara Indonesia.

ii. orang perseorangan warga negara asing.

iii. badan hukum Indonesia/asing.

iv. badan usaha Indonesia/asing

v. lembaga internasional (Peraturan Otoritas Jasa Keuangan Nomor 77 tahun 2016 tentang Penyelenggaran Layanan Pinjam Meminjam Berbasis Teknologi Informasi Pasal 16).

Dalam pelaksanaan transaksi syariah, lembaga jasa keuangan wajib tunduk pada peraturan penyelenggaran layanan berdasarkan syariah yang dikeluarkan oleh pihak terkait. Namun sampai saat ini Otoritas Jasa Keuangan maupun Dewan Syariah Nasional Majelis 
Ulama Indonesia belum menerbitkan peraturan ataupun fatwa terkait penyelenggaraan layanan pendanaan SBSN berbasis teknologi informasi yang berdasarkan syariah.

Namun jika merujuk pada fatwa No 117/DSN-MUI/II/2018, Tentang Layanan Pembiayaan Berbasis Teknologi Informasi Berdasarkan Prinsip Syariah, terdapat beberapa ketentuan terkait Pedoman umum Layanan Pembiayaan Berbasis Teknologi Informasi, antara lain:

a. Penyelenggaraan Layanan Pembiayaan berbasis teknologi informasi tidak boleh bertentangan dengan prinsip Syariah, yaitu antara lain terhindar dari ribâ, gharar, maysir, tadlis, dharar, zhulm, dan haram;

b. Akad Baku yang dibuat Penyelenggara wajib memenuhi prinsip keseimbangan, keadilan, dan kewajaran sesuai syariah dan peraturan perundang-undangan yang berlaku;

c. Akad yang digunakan oleh para pihak dalam penyelenggaran Layanan Pembiayaan berbasis teknologi informasi dapat berupa akad-akad yang selaras dengan karakteristik layanan pembiayaan, antara lain akad al-bai', ijârah, mudhârabah, musyârakah, wakâlah bil ujrah, dan qardh;

d. Penggunaan tanda tangan elektronik dalam sertifikat elektronik yang dilaksanakan oleh Penyelenggara wajib dilaksanakan dengan syarat terjamin validitas dan autentikasinya sesuai dengan peraturan perundangan-undangan yang berlaku;

e. Penyelenggara boleh mengenakan biaya (ujrah/rusun) berdasarkan prinsip ijarah atas penyediaan sistem dan sarana prasarana Layanan Pembiayaan Berbasis Teknologi Informasi.

f. Jika informasi pembiayaan atau jasa yang ditawarkan melalui media elektronik atau diungkapkan dalam dokumen elektronik berbeda dengan kenyataannya, maka pihak yang dirugikan memiliki hak untuk tidak melanjutkan transaksi (Fatwa DSN-MUI No 117/DSN-MUI/II/2018, Tentang Layanan Pembiayaan Berbasis Teknologi Informasi Berdasarkan Prinsip Syariah).

Untuk mencapai hal tersebut, maka dalam peraturan lembaga jasa keuangan syariah diatur mengenai kepatuhan syariah (syariah compliance) yang kewenangannya berada pada Majelis Ulama Indonesia yang direpresentasikan melalui Dewan Pengawas Syariah yang harus dibentuk pada masing-masing Penyelenggara Layanan

ANALISIS PENERAPAN AKAD WAKALAH PADA PRODUK 
pinjam meminjam berbasis teknologi informasi yang berdasarkan syariah.

Jika terjadi perselisihan antar para pihak selama akad berlangsung maka Penyelesaian sengketa di antara para pihak dapat dilakukan melalui musyawarah mufakat. Apabila musyawarah mufakat tidak tercapai, maka penyelesaian sengketa dilakukan melalui lembaga penyelesaian sengketa berdasarkan syariah sesuai peraturan perundang-undangan yang berlaku.

Kepatuhan Syariah merupakan prinsip utama sebagai bentuk perlindungan hukum preventif bagi para pengguna jasa layanan yang harus dipenuhi sekaligus sebagai pembeda dengan Penyelenggara Layanan jasa keuangan konvensional. Dengan kata lain kepatuhan syariah dalam layanan pinjam meminjam berbasis teknologi informasi adalah tercipta dan terpenuhinya budaya kepatuhan pada prinsip syariah serta perundang-undangan yang berlaku dalam bidang muamalah (transaksi fintech berbasis syariah) termasuk moral etika dalam setiap aktivitasnya (Alwi, 2018).

\section{Akad Wakalah}

\section{Pengertian Wakalah}

Secara terminologis, Syekh Wahbah Al-Zuhaili mengatakan bahwa wakalah memiliki dua pengertian, yang pertama mengartikan wakâlah sebagai pendelegasian suatu tindakan hukum kepada orang lain yang bertindak sebagai wâkil. Sedangkan yang kedua, mengartikan wakalah sebagai pendelegasian hak kepada seseorang dalam hal-hal yang bisa diwakilkan kepada orang lain selagi orang tersebut masih hidup (Djamil, 2013:189).

Jadi pada akad itu seseorang menunjuk orang lain sebagai wakilnya dalam bertindak. Menurut fatwa DSN-MUI wakalah yaitu pelimpahan kekuasaan oleh suatu pihak kepada pihak lain dalam halhal yang boleh diwakilkan (Fatwa DSN-MUI No. 10 tentang Wakalah). Dalam kasus pendanaan sukuk, akad yang digunakan investor selaku pemberi kuasa adalah SBSN wâkalah, yaitu pemberian kuasa dari investor kepada penerbit SBSN untuk mengelola dananya dalam bentuk investasi, yang kemudian para investor mendapatkan imbalan (upah) atas modal/dana yang telah di investasikan. 


\section{Rukun dan Syarat Wakalah}

Terdapat beberapa Rukun dan syarat pada transaksi dengan dasar hukum akad wak â lah, antara lain:

a. Syarat-Syarat orang yang di wakilkan (muwakkil)

i. Pemilik sah yang dapat bertindak terhadap sesuatu yang diwakilkan.

ii. Orang mukallaf atau anak mumayyiz dalam batas-batas tertentu, yakni dalam hal-hal yang bermanfaat baginya seperti mewakilkan untuk menerima hibah, menerima sedekah dan sebagainya. Maka orang yang tidak cakap bertindak hukum seperti gila, anak kecil, dungu, tidak boleh mendelegasikan suatu hak kepada orang lain karena dia sendiri belum cakap bertindak.

b. Syarat-syarat orang yang mewakili (wakil)

i. Cakap hukum, artinya orang tersebut memiliki pengetauan yang memadai tentang masalah yang diwakilkan kepadanya. Imam Malik dan Imam Syafi'i berpendapat bahwa tidak sah memberi kuasa kepada anak di bawah umur, orang gila dan orang fasiq (rusak akhlaknya).

ii. Mampu mengerjakan tugas yang diwakilkan kepadanya, maka penunjukan w â kil harus tegas sehingga benar-benar tertuju kepada wakil yang dimaksud.

iii. Wakil adalah orang yang diberi amanat, artinya orang yang menerima kuasa harus menjaga amanat muwakkil dan tidak boleh menggukan kuasa tersebut untuk kepentinggan dirinya di luar yang disetujui oleh pemberi kuasa (Djamil, 2013:191).

c. Hal-hal yang diwakilkan

i. Diketahui dengan jelas oleh orang yang mewakili, artinya objek wakalah haruslah jelas yaitu berupa sesuatu yang dapat dijadikan objek akad atau suatu pekerjaan yang dapat dikerjakan oleh orang lain.

ii. Tidak bertentangan dengan syariah Islam, artinya hal tersebut haruslah perkara-perkara yang mubah dan dibenarkan oleh syara'.

iii. Dapat diwakilkan menurut syariah Islam, artinya objek akad tersebut haruslah memiliki identitas yang jelas serta sah milik muwakkil. 


\section{d. Ketentuan Terkait Ujrah}

i. Ujrah boleh berupa barang atau uang yang muttaqowam, yang artinya dapat dimanfaatkan menurut syariah serta peraturan perundang-undangan yang berlaku.

ii. Kuantitas dan kualitas ujrah harus jelas, baik berupa angka nominal, presentase tertentu atau rumus yang disepakati dan diketahui oleh para pihak yang melakukan akad.

iii. Ujrah boleh dibayar secara tunai, berangsur-angsur, dan tangguh sesuai dengan syariah, kesepakatan, atau peratura perundang-undangan yang berlaku.

iv. Ujrah yang telah disepakati boleh ditinjau ulang atas manfaat yang belum diterima muwakkil sesuai kesepakatan (Fatwa DSN-MUI NO.10/DSN-MUI/IV/2000 tentang Wakâlah).

\section{Berakhirnya Akad Wakalah}

Perjanjian menggunakan akad wakalah dapat berakhir disebabkan beberapa hal berikut:

a. Matinya salah seorang dari shâhibul akad (orang-orang yang berakad), atau hilangnya kecakapan hukum.

b. Bila salah seorang yang berakad menjadi gila, karena salah satu syarat sahnya sebuah akad yaitu dijalankan oleh orang yang berakal.

c. Dihentikanya aktivitas/pekerjaan dimaksud oleh kedua pihak.

d. Pembatan akad oleh pemberi kuasa (muwakkil) terhadap penerima kuasa (wakil). Menurut mazhab Hanafi, jika hal ini terjadi maka wakil wajib mengetahui putusan pembatalan/pemutusan akad tersebut karena sebelum wakil mengetahui hukum segala tindakan itu tidak ubahnya seperti sebelum diputuskan. Sedangkan menurut pendapat mazhab Syafi'i dan Hambali pemutusan akad oleh muwakkil kepada $\mathrm{w}$ â kil tetap sah meskipun wakil belum mengetahui (Suhendi, 2010:237).

e. Penerima kuasa mengundurkan diri dengan sepengetahuan pemberi kuasa.

f. Gugurnya hak kepemilikan atas objek akad bagi pemberi kuasa (Djamil, 2013:194). 


\section{METODE PENELITIAN}

Penelitian adalah kegiatan yang dilakukan dengan suatu sistematika dan metodologi ilmiah untuk memperoleh suatu yang baru dalam usaha memecahkan masalah yang timbul di masyarakat (Sukandarrumidi, 2012). Untuk mendapatkan hasil yang maksimal, dalam penelitian ini penulis menggunakan metode penelitian sebagai berikut:

\section{Jenis Penelitian}

Penelitian ini menggunakan metode kualitatif, yaitu penelitian yang menghasilkan data deskriptif dan tertulis dengan memadukan antara penelitian kepustakaan (library research) dan penelitian lapangan (field research). Sehingga data-data penelitian ini diperoleh melalui studi pustaka dengan mengambil berbagai sumber dan literatur yang terkait dengan rumusan masalah.

Pendekatan kualitatif ini ialah penelitian untuk menjawab permasalahan yang memerlukan pemahaman secara mendalam dalam konteks waktu dan situasi yang bersangkutan, dilakukan sesuai dengan kondisi objektif di lapangan. Dalam penelitian lapangan (field research) ini penulis mengumpulkan data dengan metode wawancara dan observasi di platform fintech syariah Investree, sedangkan untuk data tambahan penulis menggunakan dokumen, jurnal, peraturan, buku-buku, dan karya ilmiah yang berkaitan dengan teori SBSN/sukuk, fintech, dan wakâlah.

\section{Pendekatan Penelitan}

Metode pendekatan yang digunakan adalah pendekatan kualitatif, yaitu metode dengan wawancara mendalam, observasi terlibat, serta pengumpulan dokumen. Dalam penelitian ini, penulis melakukan wawancara dan pengumpulan data dari PT. Investree Radhika Jaya. Sedangkan penelitian deskriptif bertujuan menggambarkan objek penelitian dengan lebih teliti, menentukan terjadinya frekuensi objek tersebut, serta prosedur penelitian harus mengikuti ketentuanketentuan yang ada (Afrizal, 2015:113).

\section{Sumber Data}

Sumber data dari karya tulis ilmiah ini terbagi menjadi dua, yaitu sumber data primer dan sumber data skunder.

\section{a. Sumber data Primer}

Sumber data primer dalam penelitian ini adalah sumber data dari lapangan atau lokasi penelitian, hal ini dapat dilakukan

ANALISIS PENERAPAN AKAD WAKALAH PADA PRODUK 
dengan metode wawancara ataupun observasi yang dilakukan di PT. Investree Radhika Jaya.

\section{b. Sumber data Sekunder}

Sumber data sekunder dilakukan melalui pengumpulan kepustakaan yang dapat mendukung data primer, hal ini dapat dilakukan dengan metode studi kepustakaan serta dokumentasi.

\section{Metode Pengumpulan Data}

Penelitian kualitatif berupaya mengungapkan kondisi perilaku masyarakat di lingkungan sekitar. Maka untuk menjalankan tuntunan metode ini, menepatkan manusia sebagai figur terpenting dalam penelitian (Gunawan, 141-142). Data penelitian kualitatif diperoleh dari sumber data dengan menggunkan teknik pengumpulan sebagai berikut:

a. Observasi (Pengamatan)

Istilah observasi diarahkan pada kegiatan yang akurat, mencatat fenomena yang muncul, dan mempertimbangkan hubungan antara aspek dan fenomena tersebut.

b. Studi Lapangan (Field Research)

Studi Lapangan (Field Research) yaitu Pengumpulan data secara langsung ke lapangan. Metode ini dapat berupa wawancara yang ditunjukan untuk mendapat informasi dari satu sisi sehingga menunjukan hubungan asimestris.

c. Dokumentasi

Sumber data yang digunakan untuk melengkapi penelitian, baik berupa sumber tertulis maupun karya-karya monumental yang semuanya memberikan informasi bagi proses penelitian (Gunawan, 2013:143).

d. Triangulasi

Teknik pengumpulan data yang bersifat menggabungkan berbagai teknik dan sumber data yang sudah ada. Dalam hal ini penulis mengabungkan hasil observasi, wawancara serta dokumentasi yang ada. 


\section{Analisis Pendanaan Sukuk Tabungan melalui Financial Technology Syariah Berdasarkan Fatwa DSN-MUI.}

Sukuk merupakan nama lain dari obligasi syariah, sesuai fatwa DSNMUI No.32/DSN-MUI/IX/2002 obligasi yang selama ini dijadikan sebagai surat hutang dengan kewajiban membayar bunga merupakan praktik pendanaan yang tidak sesuai dengan prinsip syariah (Fatwa DSN-MUI Nomor 32/DSN-MUI/IX/2002 Tentang Obligasi Syariah).

Maka dari itu pemerintah menerbitkan obligasi berdasarkan pedoman Dewan Syariah Nasional-Majelis Ulama Indonesia yang kemudian disebut obligasi syariah atau sukuk. Dalam Fatwa DSN-MUI Nomor 69/DSN-MUI/VI/2018 dijelaskan bahwa Sukuk Negara atau dapat disebut Surat Berharga Syariah Negara adalah Surat Berharga Negara yang diterbitkan berdasarkan prinsip syariah, sebagai bukti kepemilikan atas bagian dari aset SBSN, baik dalam mata uang rupiah maupun valuta asing (Fatwa DSN-MUI Nomor 69/DSN-MUI/VI/2018 tentang Surat Berharga Syariah Negara).

Hingga saat ini pemerintah telah menerbitkan 7 macam jenis sukuk, dua di antaranya yang diperdangkan untuk WNI (Ritel) ialah Sukuk Negara Ritel dengan akad Ijârah Asset to be Leased dan Sukuk Negara Tabungan dengan akan SBSN Wakâlah. Sukuk Tabungan yang dibahas merupakan sukuk negara yang dijual kepada investor individu WNI melalui Agen Penjual dengan tenor selama 2 tahun.

Sukuk Tabungan adalah sukuk negara yang merupakan produk investasi syariah. Sukuk ini diterbitkan oleh Pemerintah yang kemudian dijual kepada investor individu Warga Negara Indonesia melalui Agen Penjual dengan tenor selama 2 tahun, minimal pembelian 1 juta Rupiah dan kelipatanya, serta maximum order 3 miliar. Sukuk Tabungan tidak dapat diperdagangkan seperti halnya sukuk ritel negara, namun memiliki fasilitas early redemption. Struktur akad yang digunakan dalam penerbitan Sukuk Tabungan adalah akad Wakalah (Direktorat Jenderal Pengelolaan Pembiayaan dan Risiko Kementerian Keuangan Republik Indonesia, 2019).

Surat Berharga Syariah Negara Wakalah (SBSN Wakalah) atau dalam istilah fikih disebut sebagai wak â lah bil istitsmar, yaitu SBSN yang diterbitkan berdasarkan prinsip syariah, sebagai bukti kepemilikan atas bagian dari aset dalam kegiatan investasi yang dikelola oleh Perusahaan Penerbit SBSN selaku Wakil dari pernegang SBSN. Penerbit SBSN wajib menyatakan bahwa dirinya bertindak

ANALISIS PENERAPAN AKAD WAKALAH PADA PRODUK 
sebagai Wali Amanat atau Wakil dari pemegang SBSN, untuk mengelola dana hasil penerbitan SBSN dalam berbagai kegiatan yang menghasilkan keuntungan.

Penerbit SBSN sebagai Wakil dalam pengelolaan dana hasil penerbitan SBSN wajib:

a. Menyampaikan kepada calon investor tentang rencana penggunaan dana dalam berbagai kegiatan yang akan dilakukannya.

b. Menyampaikan jenis akad wakalah yang digunakan, yaitu wakalah tanpa ujrah (wakalah bi dunil ujrah) atau wak â lah dengan ujrah (wakalah bil ujrah). Dalam hal wak â lah bil ujrah, Penerbit SBSN wajib menyampaikan jumlah ujrah dan waktu pengenaannya.

c. menggunakan dana tersebut dalam berbagai kegiatan yang menguntungkan, baik berupa kegiatan ijarah (sewa menyewa), tijarah (seperti pengadaan barang dan jasa) dan kegiatan lainnya yang sesuai dengan prinsip syariah.

d. menjaga komposisi kegiatan penggunaan sebagian besar dana atau sekurang-kurangnya 51\% dalam bentuk aset berwujud dalam hal SBSN Wakâlah diterbitkan untuk dapat diperdagangkan (tradeable) di pasar sekunder.

e. menginformasikan penggunaan dana dalam kegiatan yang dilakukannya seperti jenis kegiatan dan perhitungan keuntungan masing-masing kegiatan.

f. menginformasikan kepada investor apabila terdapat perbedaan antara pelaporan penggunaan dana dengan rencana yang telah disampaikan.

g. menyerahkan sepenuhnya keuntungan yang diperoleh kepada pemegang SBSN dalam bentuk Imbalan SBSN secara periodik dan/atau pada saat jatuh tempo sesuai kesepakatan.

h. menjelaskan dan mendapat opini syariah apabila terjadi penggunaan dana yang diragukan kepatuhan syariahnya (Fatwa DSN-MUI No 95/DSN-MUI/VII/2014 tentang SBSN Wakalah).

Berikut Struktur Dasar Akad SBSN Wakâlah (Memorandum Informasi Sukuk Tabungan Seri ST006 (Green Sukuk Ritel) Dalam Mata Uang Rupiah Dengan Akad Wakâlah, 2019): 


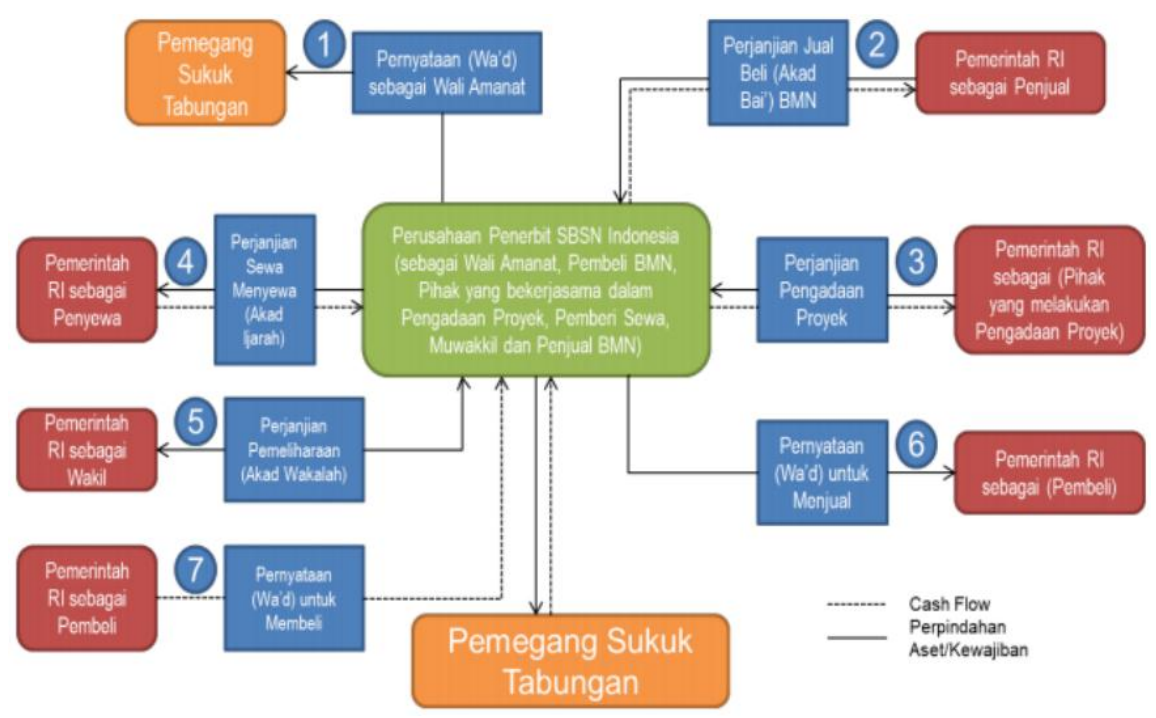

\section{Keterangan:}

I. Penerbitan SBSN

a. Perusahaan Penerbit SBSN Indonesia (SPV) menyatakan dirinya bertindak sebagai Wali Amanat/Wakil dari pemegang SBSN untuk mengelola dana hasil penerbitan ke dalam berbagai kegiatan yang menghasilkan keuntungan.

b. SPV menyampaikan kepada calon investor tentang rencana penggunaan dana dalam berbagai kegiatan yang akan dilakukan.

c. Dengan menyetujui form pemesanan, Investor memberikan kuasa kepada Perusahaan Penerbit SBSN Indonesia (Wakil) untuk mengelola dana penerbitan sukuk ke dalam kegiatan investasi yang menghasilkan keuntungan.

d. Penerbitan sukuk. Nilai nominal sukuk yang diterbitkan setara dengan rencana kegiatan investasi yang akan dilakukan.

II. Pembayaran Imbalan

a. Dana hasil penerbitan dikelola oleh SPV untuk diinvestasikan ke dalam kegiatan yang menghasilkan keuntungan. Komposisi aset berwujud yang digunakan adalah sebesar maksimum $50 \%$, sehingga Sukuk Tabungan tidak dapat diperdagangkan di pasar sekunder (non-tradable).

b. Kegiatan investasi: 
1) SPV membeli Barang Milik Negara dari Pemerintah, kemudian menyewakannya kembali kepada Pemerintah melalui akad ijarah (sale and lease back). Nilai kegiatan ini setara maksimum $50 \%$ dari total penerbitan SBSN.

2) SPV melakukan kontrak procurement aset tetap yang memiliki masa manfaat lebih dari satu tahun dengan Pemerintah. Nilai kegiatan ini setara minimum 50\% dari total penerbitan SBSN. Hasil procurement tersebut akan disewakan kepada Pemerintah melalui akad Ijarah. Kewajiban pembayaran procurement fee oleh SPV akan diset-off dengan kewajiban pembayaran ujrah oleh Pemerintah.

3) Imbalan berasal dari keuntungan investasi, berupa uang sewa (ujrah) dari hasil penyewaan Barang Milik Negara, yang dibayar secara periodik.

III. Jatuh Tempo

Pada saat jatuh tempo, Pemerintah akan membeli Aset SBSN dari investor dengan harga sesuai kesepakatan melalui akad Bai'. Harga pembelian Aset SBSN kemudian dibayarkan kepada investor sebagai pelunasan sukuk (Memorandum Informasi Sukuk Tabungan Seri ST006 (Green Sukuk Ritel) Dalam Mata Uang Rupiah Dengan Akad Wakalah).

Pada Fatwa DSN-MUI No. 95/DSN-MUI/VII/2014 tentang Surat Berharga Syariah Negara (SBSN) Wakâlah terdapat beberapa ketentuan umum dan ketentuan khusus yang menjelaskan terkait penyelenggaan pendanaan sukuk dengan akad wakâlah, terdiri dari :

\section{Ketentuan Umum}

a. SBSN Wakâlah: SBSN wakâlah bit istitsmar; yaitu SBSN yang diterbitkan berdasarkan prinsip syariah, sebagai bukti kepemilikan atas bagian dari aset dalam kegiatan investasi yang dikelola oleh Perusahaan Penerbit SBSN selaku Wakil dari pemegang SBSN;

b. Aset SBSN Wakâlah : aset yang berupa barang, jasa, proyek, atau asset lainnya yang sesuai dengan prinsip syariah sebagai dasar (underlying) penerbitan SBSN Wakâlah (Fatwa DSN-MUI Nomor 95/DSN-MUI/VII/2014 Tentang SBSN Wakâlah).

Dari Ketentuan umum di atas, platform investree sebagai wâkil dari pemerintah selaku penerbit sukuk telah menjalankan tugasnya sesuai pedoman prinsip syariah. Di mana dalam prosesnya investree 
menggunakan sistem e-sbn (online system) yang menghubungkan antara pemerintah selaku penerbit SBSN dan investor SBSN. Pada saat registrasi, para investor atau calon investor SBSN akan menerima dokumen berupa sertifikat elektronik yang berisi ketentuan-ketentuan terkait sebagai akad perjanjian tertulis yang menerangkan kontrak kerjasama dan disetujui oleh investor SBSN.

\section{Ketentuan Khusus}

a. Penerbitan SBSN dapat dilakukan secara langsung oleh Pemerintah atau melalui Perusahaan Penerbit SBSN;

b. Penerbit SBSN wajib menyatakan bahwa dirinya bertindak sebagai Wali Amanat/ Wâkil dari pemegang SBSN, untuk mengelola dana hasil penerbitan SBSN dalam berbagai kegiatan yang menghasilkan keuntungan;

c. Penerbit SBSN wajib menerbitkan SBSN Wakâlah;

d. Penerbit SBSN sebagai Wâkil dapat menjamin dana investor;

e. Penerbit SBSN sebagai Wâkil dalam pengelolaan dana hasil penerbitan SBSN wajib:

i. menyampaikan kepada calon investor tentang rencana penggunaan dana dalam berbagai kegiatan yang akan dilakukannya, antara lain rencana jenis kegiatan, dan perkiraan keuntungan masing-masing kegiatan;

ii. menyampaikan jenis akad wakâlah yang digunakan, yaitu wakâlah tanpa ujrah (wakâlah bi dunil ujrah) atau wakâlah dengan ujrah (wakâlah bil ujrah). Dalam hal wakâlah bil ujrah, Penerbit SBSN wajib menyampaikan jumlah ujrah dan waktu pengenaannya;

iii. menggunakan dana tersebut dalam berbagai kegiatan yang menguntungkan, baik berupa kegiatan ijârah (sewa menyewa), tijârah (seperti pengadaan barang dan jasa) dan kegiatan lainnya yang sesuai dengan prinsip syariah;

iv. menjaga komposisi kegiatan penggunaan sebagian besar dana atau sekurang-kurangnya $51 \%$ dalam bentuk aset berwujud dalam hal SBSN Wakâlah diterbitkan untuk dapat diperdagangkan (tradeable) di pasar sekunder;

v. menginformasikan penggunaan dana dalam kegiatan yang dilakukannya antara lain jenis kegiatan, 
perhitungan keuntungan masing-masing kegiatan, dan perhitungan keuntungan kegiatan;

vi. menginformasikan kepada investor apabila terdapat perbedaan antara pelaporan penggunaan dana dengan rencana yang telah disampaikan;

vii. menyerahkan sepenuhnya keuntungan yang diperoleh kepada pemegang SBSN dalam bentuk Imbalan SBSN secara periodik dan/atau pada saat jatuh tempo sesuai kesepakatan;

viii. menjelaskan dan mendapat opini syariah apabila terjadi penggunaan dana yang diragukan kepatuhan syariahnya.

f. Dalam melakukan kegiatannya Penerbit SBSN:

i. dapat melakukan transaksi dengan Pemerintah dan/atau pihak lain;

ii. dapat memberikan kuasa (wakâlah) kepada Pemerintah atau pihak lain yang ditunjuk dalam rangka melakukan pengadaan dan/atau pengelolaan Aset SBSN;

iii. wajib memperhatikan substansi fatwa DSN-MUI terkait akad-akad yang digunakan dalam melakukan kegiatan investasi; dan/atau

iv. dapat menerima ujrah, dalam hal wakâlah dilakukan dengan akad wakâlah bil ujrah.

g. Penerbit SBSN dilarang:

i. melakukan kegiatan di luar wewenang yang diberikan dalam akad wakâlah;

ii. mengambil atau menerima keuntungan dari hasil kegiatan investasi; dan/atau

iii. mengambil ujrah selain yang telah disepakati dalam akad wakâlah bil ujrah.

h. Pemerintah dapat membeli sebagian atau seluruh Aset SBSN Wakâlah sebelum jatuh tempo, dengan membayar harga sesuai dengan kesepakatan.

i. Untuk pembelian Aset SBSN Wakâlah sebelum jatuh tempo, para pihak melakukan perubahan atau pengakhiran akad SBSN Wakâlah (Fatwa DSN-MUI Nomor 95/DSN-MUI/VII/2014 Tentang SBSN Wakâlah). 
Akad wakâlah yang terjadi antara pemerintah selaku penerbit SBSN dengan investree selaku agen penjual adalah akad wakâlah bil ujrah. Dalam hal ini pemerintah betindak sebagai muwakkil sedangkan pihak investree bertindak menjadi wakil dari pemerintah dalam memasarkan pendanaan sukuk kepada masyarakat. Sehingga pihak investree selaku wakil, berkewajiban untuk menjalankan hal-hal yang harus dilakuakan oleh penerbit SBSN sesuai dengan pedoman fatwa nomor 95 tahun 2014 tentang SBSN wakâlah.

Kemudian akad antara investree dan investor ialah akad wakâlah (wakâlah bi dunil ujrah), sehingga dalam hal ini investor bertindak selaku muwakkil yang menyerahkan pengelolaan dananya kepada investree selaku wâkil. Pada mekanismenya, pelaksanaan akad wakâlah pada pendanaan sukuk tabungan di platform fintech syariah investree telah sesuai dengan metode pendanaan SBSN wakâlah yang tertuang dalam fatwa DSN-MUI.

Setelah memaparkan beberapa ketentuan terkait fatwa DSN-MUI No.95/DSN-MUI/VII/2014 penulis mengambil kesimpulan bahwasanya praktik pendanaan sukuk tabungan yang terjadi di PT. Investree Radhika Jaya telah sesuai dengan ketentuan khusus yang tertuang dalam fatwa SBSN Wakâlah.

\section{Ketentuan Hukum}

Penerbitan SBSN wakâlah boleh dilakukan dengan mengikuti ketentuan yang terdapat pada fatwa DSN-MUI No.95/DSNMUI/VII/2014 tentang Surat Berharga Syariah Negara (SBSN) Wakâlah dengan tetap memperhatikan fatwa DSN No.10/DSN-MUI/IIV/2000 tentang Wakâlah dan Fatwa DSN No.69/DSN-MUI/II/2008 tentang Surat Berharga Syariah Negara.

Jika terjadi perselisihan di antara para pihak, maka penyelesaiannya dilakukan berdasarkan peraturan perundangundangan yang berlaku dan sesuai prinsip syariah (Fatwa DSN-MUI Nomor 95/DSN-MUI/VII/2014 Tentang SBSN Wakâlah).

\section{KESIMPULAN}

Penulis menyimpulkan beberpa hal untuk menjawab rumusan masalah yang telah dikemukakan dalam penelitian ini, di antaranya sebagai berikut :

1. Praktik pendanaan Sukuk Tabungan yang diterapkan di PT Investree Radhika Jaya sama dengan Agen Penjual sukuk tabungan

\footnotetext{
ANALISIS PENERAPAN AKAD WAKALAH PADA PRODUK 
lainnya, akan tetapi Investree merupakan satu-satunya agen penjualan sukuk negara yang berjenis fintech syariah. Dengan metode e-sbn, para investor cukup mendaftar sebagai lender yang telah memiliki akun Investree, kemudian para investor dapat mendanai surat berharga negara yang ada. Setelah itu investor akan diberikan surat kuasa elektronik yang berisi pernyataan bahwasanya investor selaku muwakkil memberikan kuasa kepada pihak investree yang bertindak sebagai wâkil guna mengelola dana investasi yang telah disetorkan. Selanjutnya investor melakukan transfer melalui bank persepsi untuk menyetorkan uang sesuai dengan jumlah sukuk yang didanai, kemudian investor akan menerima tanda bukti kepemilikan sukuk di akun investreenya.

2. Hasil analisis pendanaan Sukuk Tabungan di PT. Investree Radhika Jaya telah sesuai dengan aturan yang berlaku, yakni berdasarkan peraturan yang tertuang dalam Memorandum Informasi Sukuk Tabungan dengan akad wakâlah yang dikeluarkan oleh Kementerian Keuangan Republik Indonesia khususnya mengenai mekanisme pendanaan sukuk tabungan.

3. Hasil Analisis yang didapat dari penelitian mengenai pendanaan sukuk tabungan dengan akad SBSN wakâlah melalui fintech syariah investree telah sesuai dengan fatwa DSN-MUI No.95/DSNMUI/VII/2014.

\section{DAFTAR PUSTAKA}

Afrizal. (2015). Metode Penelitian Kualitatif. Jakarta: PT. Rajagrafindo Persada.

Aldila, Nindya. Investree Luncurkan Produk Syariah pertama yang Teregistrai OJK. https://m.bisnis.com/ diakses tanggal 21 Desember 2019.

Alwi, Ahmad Basori. (2018). Pembiayaan Berbasis Teknologi Informasi (Fintech) yang Berdasarkan Syariah. Jurnal Al-Qanun, Vol.21(2).

Basuki, Ferry Hendro dan Hartina Husein. (2018). Analisis SWOT Financial Technology Pada Dunia Perbankan di Kota Ambon (Survei pada Bank di Kota Ambon). Jurnal Manis Universitas Pattimura Ambon, Vol.2 (1). 
Darmawanysah, Trisna Taufik dan Yani Aguspriyani. (2019). Implementasi Fintech Syariah Di PT Investree Ditinjau Berdasarkan Fatwa Dsn-Mui No: 117/DSN-MUI/II/2018 Tentang Layanan Pembiayaan Berbasis Teknologi Informasi Berdasarkan Prinsip Syariah. Jurnal Ekonomi dan Bisnis Islam, Vol.3(2).

Direktorat Jenderal Pengelolaan Pembiayaan dan Risiko Kementerian Keuangan Republik Indonesia. Frequently Asked Questions (FAQ) Sukuk Tabungan Seri ST005. Jakarta 6 Agustus 2019.

Direktorat Pembiyaan syariah Kementrian Keuangan RI. (2019). Investasi Hijau Menjaga Bumi. dalam Brosur Kementrian Keuangan RI. Jakarta, 1 November 2019.

Djamil, Fathurrahman. (2013). Penerapan Hukum Perjanjian dalam Transaksi di Lembaga Keuangan Syariah. Jakarta: Sinar Grafika.

Fatwa DSN-MUI Nomor 32/DSN-MUI/IX/2002 Tentang Obligasi Syariah.

Fatwa DSN-MUI Nomor 69/DSN-MUI/VI/2018 tentang Surat Berharga Syariah Negara.

Fatwa DSN-MUI Nomor 95/DSN-MUI/VII/2014 Tentang SBSN Wakalah.

Fatwa DSN-MUI No 117/DSN-MUI/II/2018, Tentang Layanan Pembiayaan Berbasis Teknologi Informasi Berdasarkan Prinsip Syariah.

Gunawan, Imam. (2013). Metode Penelitian Teori dan Praktek. Jakarta: Bumi Aksara.

Huda, Nurul dan Mustafa Edwin Nasution. (2008). Investasi Pada Pasar Modal Syariah. Jakarta: Kencana.

Laman resmi Rirektorat Jendral Pengelolaan Pembiayaan dan Resiko, www.djppr.kemenkeu.go.id diakses pada tanggal 1 Juni 2020.

Pemerintah Republik Indonesia. Memorandum Informasi Sukuk Tabungan Seri ST006 (Green Sukuk Ritel) Dalam Mata Uang Rupiah Dengan Akad Wakâlah? Jakarta, 1 November 2019.

Peraturan Bank Indonesia No. 19/12/PBI/2017 tentang Penyelenggaraan Teknologi Finansial.

Peraturan Otoritas Jasa Keuangan Nomor 77 tahun 2016 tentang Penyelenggaran Layanan Pinjam Meminjam Berbasis Teknologi Informasi. 
Pramana, I Wayan Bagus. (2014). Peran Otoritas Jasa Keuangan Dalam Mengawasi Lembaga Keuangan Non Bank Berbasis Financial Technolgy. Jurnal Ilmu Hukum, Vol.02(04).

Rahayu, Ning. Investree Juga Kantongi Restu OJK dalam Warta Ekonomi. Jakarta, Jumat, 17 Mei 2019.Zuraya, Nida dan Retno Wulandari. Investree Syariah Salurkan Pembiayaan 69 Miliyar, dalam Republika, Rabu, 22 Mei 2019.

Santi, Ernama et. al. (2017). Pengawasan Otoritas Jasa Keuangan Terhadap Financial Technology. Diponegoro Law Jurnal, Vol.6 (3).

Suhendi, Hendi. (2010). Fiqh Muamalah. Jakarta: Raja Grafindo Persada.

Sukandarrumidi. (2012). Metodologi Penelitian (Petunjuk Praktis untuk Peneliti Pemula). Yogyakarta: Gadjah Mada University Press.

Trisnadi dan Shomad, Abdul. (2005). Hukum Perbankan. Surabaya: Luthfansah Media.

Undang-Undang Nomor 19 tahun 2008 tentang Surat Berharga Syariah Negara.

Yuliandri Heru Kusumaputra. (2009). Tinjauan Mengenai Penerbitan SBSN Sebagai Instrumen Pembiayaan APBN. Tesis. Universitas Indonesia. 